\title{
Statyba
}

\section{CALCULATION METHODS OF HIGH TEMPERATURE DISTRIBUTION WITHIN STRUCTURAL COMPONENTS AND APPLICATION OF THESE METHODS TO FIRE RESISTANCE ASSESSMENT}

\section{R. Mačiulaitis \& K. Lukošius}

To cite this article: R. Mačiulaitis \& K. Lukošius (2001) CALCULATION METHODS OF HIGH TEMPERATURE DISTRIBUTION WITHIN STRUCTURAL COMPONENTS AND APPLICATION OF THESE METHODS TO FIRE RESISTANCE ASSESSMENT, Statyba, 7:5, 391-396, DOI: 10.1080/13921525.2001.10531760

To link to this article: https://doi.org/10.1080/13921525.2001.10531760

曲 Published online: 30 Jul 2012.

Submit your article to this journal $\llbracket$

Щ Article views: 82

4 Citing articles: 1 View citing articles $\pi$ 


\title{
AUKŠTŲ TEMPERATŨRU PASISKIRSTYMO STATYBINĖSE KONSTRUKCIJOSE SKAIČIAVIMO BŪDAI IR JŲ TAIKYMO ANALIZE IVERTINANT ATITVARU ATSPARUMĄ UGNIAI
}

\author{
R. Mačiulaitis, K. Lukošius \\ Vilniaus Gedimino technikos universitetas
}

\section{Ivadas}

Konstrukcijos atsparumas ugniai yra viena svarbiausių charakteristikų, apibüdinančių jos darbą gaisro metu. Kaip žinoma, atsparumas ugniai yra laikotarpis, skaičiuojamas nuo šilumos poveikio (gaisro) pradžios iki konstrukcijos stiprumo, vientisumo, termoizoliacinių ir kt. savybių netekimo, t. y. iki galimo jos suirimo ir funkcijų praradimo [1-4]. Konstrukciju projektavimo normos [3, 5-8] leidžia atsparumą ugniai skaičiuoti, atsižvelgiant $i$ konstrukcijos panaudojima, jai daromą poveiki ir tam tikrus jai keliamus reikalavimus.

Žinoti, koks yra projektuojamų ir pastatytu laikančiujų ir kitokių konstrukcijų atsparumas ugniai, reikalaujama šalies bei tarptautiniuose standartuose $[3,5,6]$. Tačiau ši laiko parametrą ívertinti nèra taip paprasta [9], nors yra žinoma gana daug metodụ jam nustatyti $[5,6,10-13]$. Galima teigti, jog tiksliausias yra eksperimentinis metodas, kai tam tikromis salygomis atliekami temperatūros matavimai, tačiau visą gaminių sortimentą taip bandyti yra pernelyg brangu. Laikančiuju konstrukciju atsparumo ugniai skaičiavimas susideda iš dviejų dalių: šilumos skaičiavimo, kuris nusako šilumos mainus konstrukcijoje gaisro metu, ir statinio skaičiavimo, kuris nustato konstrukciju laikančiają galią. Šiuo atveju laikysime kad, atitvarinès konstrukcijos atlieka tik atitvarinę funkciją, todèl pakanka tik šilumos skaičiavimo, nes statinis skaičiavimas dažniausiai taikomas tik laikančiosioms konstrukcijoms. Pagrindinis reikalavimas nagrinèjamai konstrukcijai yra izoliuoti aukštą temperatūrą gaisro patalpoje [1-3, 5]. Todèl šiame darbe plačiau nagrinèsime tik temperatūros pasiskirstymo skaičiavimą.

Svarbiausia ir tikslinga toliau nagrinèti esminius temperatūrinių laukų pasiskirstymo konstrukcijoje nusta- tymo principus bei metodus - toks ir būtų šio darbo tikslas.

\section{Atitvarinès konstrukcijos atsparumo ugniai skai- čiavimo ypatumai}

Kadangi gaisro metu vyksta sudetingi procesai, o konstrukcinių medžiagų ivairovè yra labai didelé, todèl ir temperatūros pasiskirstymo konstrukcijoje skaičiavimo būdụ yra daug ir îvairių. Esant tokiai skaičiavimo modeliu gausai trūksta išsamesnès informacijos tiek apie juos pačius, tiek ir apie ju taikymo principus. Konstrukcijų projektavimo specialistui ir gaisrinès saugos inžinieriui pravartu žinoti ir išmanyti kiekvieno metodo taikymo principus, trūkumus ir privalumus.

Atitvarinèje konstrukcijoje vykstantys procesai yra savita šilumos mainų rüšis, todèl parenkant skaičiuojamaji modelị yra daroma nemaža prielaidu.

Tikslų temperatūros pasiskirstymą konstrukcijoje skaičiavimais nustatyti trukdo gaisro proceso dinaminis pobūdis, nestacionaraus šiluminio proceso skaičiavimo sunkumai, statybinių medžiagu šiluminių charakteristikụ aukštoje temperatūroje kitimas, deformacijos atitvaros sandūrose, medžiagos destrukcija aukštoje temperatūroje, kitu pasirinktos medžiagos tiksliụ ir patikimų rodiklių stoka.

Siekiant supaprastinti šių veiksnių itaką skaičiavimo metu yra daromos tokios prielaidos:

- tiksliai nusakomas šiluminès apkrovos poveikis. Atlikus nemaža eksperimentų skirtingose šalyse $[11,14$, 15], buvo gauti gana panašūs rezultatai ir tiksliai apibrèžta gaisro standartinè temperatūros laiko kreivè [1$4,8,10,11]$. Ji taikoma tiek bandant konstrukcijas, tiek skaičiuojant jų atsparumą ugniai; 


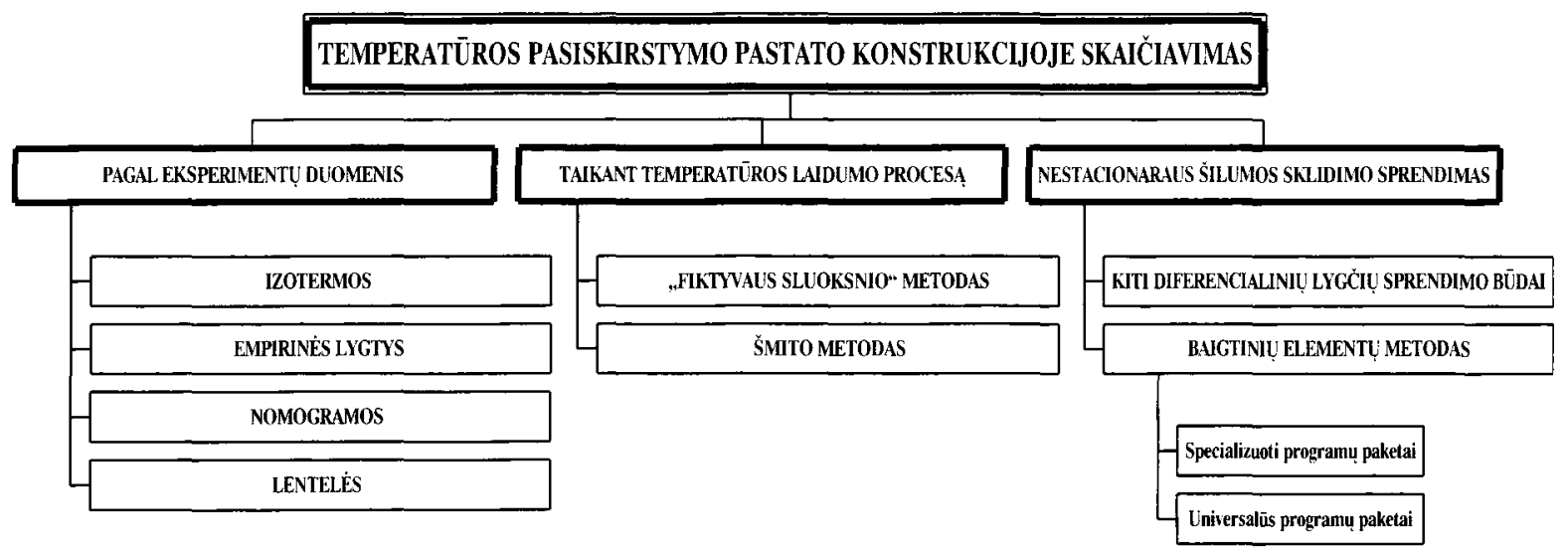

1 pav. Temperatūrinių laukų pastato konstrukcijoje galimų skaičiavimo būdų schema

Fig 1. Different temperature calculation methods within the structural component

neivertinama atitvarinès konstrukcijos deformacija, sudegimas, apanglejimas bei terminis suirimas [11, 12, 16-19]. Vykstant gaisrui konstrukcijose dèl aukštos temperatūros atsiranda didelès deformacijos, dèl kurių atitvaros sandūrose atsiveria plyšiai, taigi gaisras gali plisti toliau ir konstrukcija nebeatitinka jai keliamų reikalavimų. Plyšiai gali atsirasti konstrukcijai yrant, perdegant, trupant ir pan.;

- atitvara nagrinèjama kaip plokščia iš vienos pusès kaitinama konstrukcija.

Nagrinejant atitvarinių konstrukcijų atsparumą ugniai yra nustatomas atitvaros storis, kuris užtikrintu reikalaujamą atsparumą ugniai, arba atitvaros perkaitimo iki kritinès temperatūros neveikiamoje jos pusèje laikas $[12,20]$. Taigi būtina detalizuoti šių uždaviniu sprendimo būdus.

\section{Temperatūriniụ laukụ konstrukcijose nustatymo būdai}

Temperatūra (bet kuriame statybinès konstrukcijos taške) gali būti nustatyta yra keliais būdais (1 pav.) [5, $6,10-13]$ :

- remiantis tiesioginių eksperimentų duomenis;

- taikant medžiagų temperatūros laidumo procesą; - taikant nestacionarius šilumos sklidimo principus.

Atliekant daug tos pat rūšies konstrukcijụ bandymu, sukaupiama duomenu bazé, kuri yra izotermu, empiriniụ lygčiụ ir nomogramu sudarymo pagrindas (1 pav.). Naudojant izotermas galima gana tiksliai nustatyti konkrečios konstrukcijos atsparumą ugniai, nes dažniausiai yra pateikiami susisteminti standartinių matmenų ir charakteristikų gaminiц tyrimų duomenys. Ta- čiau pasitaiko ir nestandartinių konstrukcijų, kurioms naudojamos kiek kitokiu charakteristikų statybinès medžiagos (gaminiai su priedais, naujai sukurtos medžiagos ir pan.). Šiuo atveju izotermos paprastai nenaudojamos arba atliekami papildomi skaičiavimai (pvz., parenkamas tinkamiausias tankis, nustatomos skerspjūvio proporcijos, pasirinktame taške tiesiškai interpoliuojama temperatūra). Tačiau ir tada gauti konstrukcijos atsparumo ugniai rezultatai gali neatitikti tikrovès $[5,10$, $21,22]$.

Izotermos dažniausiai naudojamos temperatūrai gelžbetoninèse konstrukcijose nustatyti.

Empirinés lygtys, kaip ir nomogramos, taip pat gautos iš tiesioginiụ tyrimų duomenų, dažniausiai yra skirtos jau kelių kintančių medžiagu charakteristikų poveikiui (konkrečiam gaminiui) ivertinti analizuojamu aspektu. Tokiose lygtyse kintamaisiais gali būti konstrukcijos matmenys, drègmè, šilumos laidumo koeficientas, apsauginio sluoksnio rūšis ir pan. $[5,6,10,11,15,22]$.

Eksperimentiniai metodai gana dažnai taikomi praktikoje (dažniausiai naudojamos statybinès medžiagos būna pakankamai ištirtos), tačiau problemų kyla didinant konstrukcijos atsparumą ugniai, kai nukrypstama nuo standartinès konstrukcijos varianto, nes naujos apdailos ir atsparumą ugniai didinančios medžiagos bei ju priedų gausa apsunkina įtakos prognozę. Todèl visi eksperimentais pagristi metodai paprastai tinka tik konkrečioms tos pačios aibès konstrukcijoms iš tapačiu bazinių medžiagu (1 pav.). Juos taikant negalima plačiau modeliuoti konstrukcijų darbo kilus gaisrui.

Kiti atitvarinių konstrukcijų atsparumo ugniai skaičiavimai (1 pav.) pagrịsti temperatūros laidumo proce- 
su $[11,13,16]$. Šios grupés metodų esmè (2 pav.): kaitinant tariamos medžiagos paviršių (taškas O') tolygiu šilumos srautu pusiau apribotame kūne, galima rasti tokią plokštumą (taške $O$ ), kurioje temperatūra kyla pagal standartinę gaisro temperatūros ir laiko $t_{S}$ kreivę. Iš čia kilo „fiktyvaus sluoksnio" metodo pavadinimas (2 pav.), kai atstumas nuo pusiau apriboto kūno paviršiaus iki nagrinejamo taško (atstumas OO') vadinamas "fiktyviu sluoksniu“.

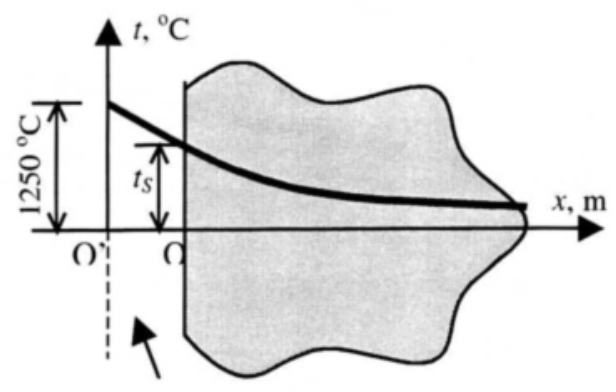

„Fiktyvus sluoksnis“

2 pav. „Fiktyvaus sluoksnio“ metodo principas

Fig 2. "Fictitious layer" method principle

Šiuo atveju vyksta temperatūros laidumo procesas medžiagoje ( 2 pav.). Juo metu dalis šilumos srauto yra sunaudojama temperatūrai kelti ịvairiuose medžiagos taškuose ir medžiagos storyje pagal $\mathrm{x}$ aši atsiranda temperatūros gradientas. Temperatūros $T$ pasikeitimo per laiką $t$ sparta kiekviename kūno ilgio $x$ taške gali būti aprašoma lygtimi $[11,16,23]$ :

$$
\frac{\partial T}{\partial t}=a \frac{\partial^{2} T}{\partial x^{2}} .
$$

Taigi skaičiuojant temperatūros pasiskirstymą medžiagoje, kai atsparumo ugniai bandymo temperatūros ir laiko kreivè yra standartinè, temperatūra bet kuriame medžiagos taške gali būti nustatoma pagal lygti:

$$
T=1250-\left(1250-T_{o}\right) \operatorname{erf} \frac{k \sqrt{a}+l}{2 \sqrt{a t}},
$$

$k$ - medžiagos tankio rodiklis; $a$ - temperatūros laidumo koeficientas; $t$ - laikas nuo kaitinimo pradžios; $x$ atstumas nuo medžiagos paviršiaus ir ,fiktyvaus sluoksnio sandūros".

Temperatūrinio laidumo proceso grafinị sprendimą pasiūle Šmitas $[11,16]$. Taikant š̉ metodą kaitinamos konstrukcijos skerspjūvis sudalijamas $\mathfrak{i}$ lygias dalis, siekiant grafiškai nustatyti temperatūrą kiekviename sluoks- nyje, kai temperatūra plokštumoje $\mathrm{n}$ lygi vidutinei dviejų gretimų plokštumų $n-1$ ir $n+1$ temperatūrai. Tai supaprastintas galinių skirtumų metodas, kuris gana sèkmingai taikomas panaudojant ESM [16].

Temperatūros laidumo proceso pritaikymas, nustatant konstrukcijos temperatūra, yra sudètingu šilumos mainų, vykstančių statybinèje konstrukcijoje, supaprastinimas. Šie metodai tinka vienalytei medžiagai, iš vienos pusès kaitinamai aukšta temperatūra (atitvaroms, plokštėms ir pan.). Tačiau jie netinka daugiasluoksnèms medžiagoms arba nèra minimos ju taikymo ribos [11, 16]. Be to, temperatūros laidumo metodai, kaip temperatūros gaisro metu nustatymo būdai konstrukcijoje, nèra itteisinti normatyviniuose dokumentuose. Todèl jie nèra plačiai paplitę.

Šiuo metu temperatūrinių laukų pasiskirstymui statybinès konstrukcijos skerspjūvyje nustatyti yra naudojami ịvairūs specializuoti programiniai paketai, kurie pagrissti baigtinių elementų skaičiavimo principais. Plačiausiai naudojami FIRES-T3, TASEF-2, THELMA ir kt. $[10,12,17-19,22,24]$. Be abejo, šiems skaičiavimams tinka ir universalūs programiniai paketai, kuriuose numatytas šiluminių uždavinių sprendimas.

Taikant baigtinių elementu metodą ( 2 pav.) galima naudoti sudètingas diferencialines lygtis, kurios gana tiksliai aprašo nestacionarius šilumos mainus konstrukcijoje. Šiuolaikiniais kompiuteriais per trumpa laiką patogioje darbo aplinkoje galima atlikti begalę matematinių veiksmu. Jiems sukurti grafiniai generatoriai, kurie labai vaizdžiai parodo apskaičiuotụ temperatūriniụ laukų išsidèstymą [18, 24].

Šio tipo metodų pranašumas išryškèja skaičiuojant skirtingu medžiagu konstrukcijoje panaudojimo bei skaičiavimo galimybes vienmateje, dvimateje ir trimateje koordinačių sistemose. Atitvarinèms konstrukcijoms skaičiuoti visiškai pakanka ir vienmatès koordinačiu sistemos, nes nagrinèjamas tik uždavinys tarp taško kaitinamame atitvaros paviršiuje ir taško, esančio nekaitinamame atitvaros paviršiuje [10, 12, 17-19, 22, 24].

Yra dar viena kompiuterinio modeliavimo rūšis, kuri vadinama CFD (computational fluid dynamic) modeliais ir grindžiama šilumos, kaip skysčio, judejjimo dèsniais $[14,22,24]$. Tokiu principu buvo sukurtas Lukjanovo hidraulinis integratorius, kurio skaičiavimo procesas yra ilgalaikis ir gana sunkus, bet gauti rezultatai pakankamai tikslüs [22] 
Minètieji metodai yra universalūs, leidžia lanksčiai ir pakankamai tiksliai nagrinèti šilumos mainus. Pagrindinè problema taikant šiuos metodus - šiluminių techninių rodikliụ stoka.

Taikant daugelị išvardytų skaičiavimo metodų reikia medžiagos šiluminių techninių charakteristikų, kurios leistų tiksliai nustatyti medžiagų savybes aukštų temperatūrų sąlygomis ir ju darbo ypatumus.

\section{Statybinių medžiagų šiluminių techninių rodikliụ ¡taka atliekant temperatūrinių laukų skaičiavimus}

Pagrindiniai šiluminiai techniniai rodikliai yra: šilumos laidumo koeficientas, šilumos talpa ir temperatūros laidumo koeficientas. Be abejo, medžiagos tankis ir drègmè taip pat yra svarbūs rodikliai, apibūdinantys medžiagos šilumines savybes. Panagrinèkime, kokia yra jų itaka skaičiavimo rezultatams.

Iš (1) lygties matome, kad temperatūros sklidimą kūne nusako temperatūros laidumo koeficientas $a$, kuris savo ruožtu priklauso nuo medžiagos santykinès šilumos talpos, šilumos laidumo koeficiento, medžiagos tankio ir kt. [11, 20, 22, 23]. Temperatūros laidumo koeficientas prilyginamas temperatūros pokyčiui, suteiktam atitinkamos medžiagos tūrio vienetui, jei suteiktas šilumos kiekis lygus šilumos laidumo koeficientui [23].

Remdamiesi temperatūros laidumo koeficiento apibrèžimu ji galime išreikšti lygtimi [23]:

$$
a=\frac{\lambda}{c \rho},
$$

$\lambda$ - šilumos laidumo koeficientas; $c$ - statybinès medžiagos specifinè šilumos talpa; $\rho$ - nagrinèjamos medžiagos tankis.

Atlikus tyrimus [11], buvo nustatyta, kad medžiagụ temperatūros laidumo koeficientas priklauso ir nuo pačios medžiagos drègmès (būdinga išorinèms konstrukcijoms) ir gali būti apskaičiuojamas taip:

$$
a=\frac{\lambda}{(c+0,012 \omega) p},
$$

$\omega$ - medžiagos eksploatacinè drégmè.

Statybinès medžiagos eksploatacinès drègmès ịtaka koeficientui gali būti išreikšta ir taip [13]:

$$
a=\frac{3,6 \lambda}{(c+0,5 \omega) p} .
$$

Akivaizdžiai matyti, kad temperatūros laidumo ko- eficiento nustatymo lygtys (3) - (5) yra skirtingos. Apskaičiavę sunkiojo betono temperatūros laidumo koeficientą pagal anksčiau pateiktas tris skirtingas išraiškas, gauname, kad (3) ir (4) lygčių rezultatai beveik nesiskiria, o lygčių (3) ir (5) rezultatai skiriasi apie 3,6 karto (3 pav.).
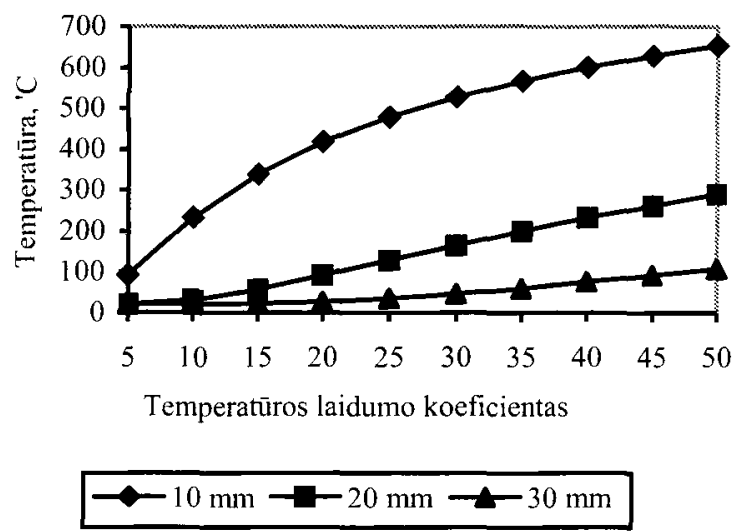

3 pav. Temperatūros ir temperatūros laidumo sąryšis taikant "fiktyvaus sluoksnio" metoda, pagal lygti (2) 10 , 20 ir $30 \mathrm{~mm}$ atstumu nuo kaitinamo paviršiaus. Tiriamoji medžiaga - sunkusis betonas, kuris kaitinamas 30 min pagal standartinę gaisro kreivę

Fig 3. Temperatures calculated by the "fictitious layer" method equation (2) 10,20 and $30 \mathrm{~mm}$ from exposed surface. Calculated material is heavy concrete, exposure time is $30 \mathrm{~min}$

Temperatūros, apskaičiuotos pagal „fiktyvaus sluoksnio" metodą, kai temperatūros laidumo koeficientas, nustatytas pagal (3) ir (5) lygtis, atitinkamai yra $212^{\circ} \mathrm{C}$ ir $553^{\circ} \mathrm{C}$ ir tarpusavyje skiriasi net apie $340^{\circ} \mathrm{C}$. Pagal izotermas galima nustatyti sunkiojo betono temperatūrą $10 \mathrm{~mm}$ atstumu nuo kaitinamo paviršiaus po 30 min temperatūros poveikio, kuri yra tarp nustatytu (apie $430^{\circ} \mathrm{C}$ ) [5]. Vadinasi, temperatūros laidumo koeficientas, nustatytas pagal (5) lygti, tiksliau ivertina sunkiojo betono temperatūros laidumo savybes. Tačiau ir šis rezultatas yra gana apytikslis.

Temperatūros laidumo koeficiento reikšmès itaka galutiniam rezultatui pateikta 3 paveiksle. Remiantis šio paveikslo kreivèmis galima teigti, kad, 4 kartus padidèjus temperatūros laidumo koeficientui, apskaičiuota temperatūra padideja 3 kartus. Kitaip tariant, nuo koeficiento $a$ tikslaus dydžio iš esmès priklauso temperatūros verte, t. y. nagrinejjamame skerspjūvio taške gali būti netiksliai nustatyta temperatūra, dèl to gali būti klaidingai apskaičiuotas ir atsparumas ugniai arba netinka- 


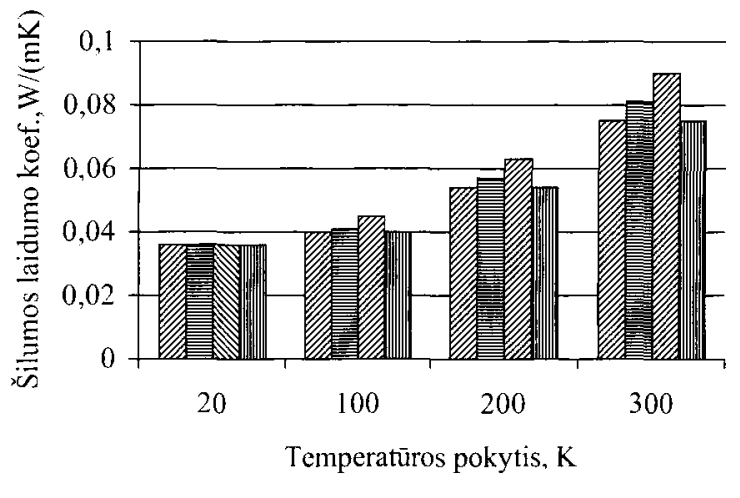

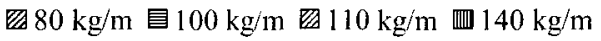

4 pav. Skirtingų tankių akmens vatos šilumos laidumo koeficientas keičiantis aplinkos temperatūrai

Fig 4. Rock-wool of different density thermal conduction dependence on environment temperature

mai apskaičiuotas apsauginio sluoksnio storis. Šis skirtumas gilesniuose sluoksniuose mažèja, t. y. žemesnèse temperatūrose skaičiavimo tikslumas didèja ( 3 pav.).

Turbūt žinomiausia statybinių medžiagų šiluminè charakteristika yra šilumos laidumo koeficientas, nes jis apie medžiagą suteikia nemaža informacijos ir yra pradinis rodiklis, padedantis nustatyti kitus išvestinius statybinès medžiagos rodiklius $[11,20,23]$. Vadinasi, taikant skaičiavimo metodus būtina imti tikslias šio koeficiento reikšmes, nes, pavyzdžiui, deklaruojamos akmens vatos šilumos laidumo koeficientas yra $0,036 \mathrm{~W} /(\mathrm{mK})$. Tačiau, atlikus skaičiavimus, nustatyta, $\mathrm{kad}$, šilumos laidumo koeficientui pakitus vos 0,004 (imant $0,04 \mathrm{~W} /(\mathrm{mK})$ ), temperatūra skaičiuojamajame taške pakyla net $35^{\circ} \mathrm{C}$.

Pažymètina, kad, nors deklaruojamas (normaliomis aplinkos sąlygomis) vienos rūšies medžiagos šilumos laidumo koeficientas yra vienodas, tačiau kylant temperatūrai jis gali būti visiškai skirtingas. Vadinasi, panašios medžiagos savybès normaliomis ekspioatavimo sąlygomis neužtikrina identiško šiluminių techniniu rodikliụ pokyčio aukštose temperatūrose. Și reiškinị akivaizdžiai iliustruoja duomenys, pateikti 4 pav.

Svarbu tai, kad $100 \mathrm{~kg} / \mathrm{m}^{3}$ tankio akmens vatos šilumos laidumo koeficientas kylant temperatūrai dideja sparčiau nei $140 \mathrm{~kg} / \mathrm{m}^{3}$ tankio akmens vatoje, o $110 \mathrm{~kg} / \mathrm{m}^{3}$ tankio akmens vatoje, kuri taip pat tankesné, šis koeficientas, palyginti su $100 \mathrm{~kg} / \mathrm{m}^{3}$, didèja lèčiau (4 pav.). Tuo tarpu $80 \mathrm{~kg} / \mathrm{m}^{3}$ tankio akmens vatos šilumos laidumo koeficientas kinta taip pat, kaip ir
$140 \mathrm{~kg} / \mathrm{m}^{3}$ tankio akmens vatos. Visụ išvardytụ tankiụ akmens vatos deklaruojamas šilumos laidumo koeficientas yra $0,036 \mathrm{~W} /(\mathrm{mK})$.

Taigi nagrinedami 4 pav. duomenis pastebime, kad tankis ir šilumos laidumo koeficientas normaliomis sąlygomis nèra lemiami šilumos laidumo koeficientui, o kartu ir temperatūros laidumo koeficiento kitimui aukštose temperatūrose.

Logiška teigti, kad ir nežymus temperatūros laidumo koeficiento skirtumas iškreipia galutinius konstrukcijos atsparumo ugniai skaičiavimo rezultatus. Nors pagrindiniai statybinių medžiagu šiluminių techninių rodiklių kitimo dèsniai ir priklausomybès yra žinomos, tačiau tikslesnius šiluminius techninius duomenis atsparioms ugniai medžiagoms aukštose temperatūrose (daugiau kaip $200^{\circ} \mathrm{C}$ ) rasti ar nustatyti yra sudètinga arba jie iš viso dar nèra patikimai ivvertinti.

\section{Išvados}

1. Yra trys pagrindiniai temperatūros bet kuriame atitvaros, veikiamos standartinio gaisro šilumine apkrova, taške apskaičiavimo principai. Skaičiavimo būdai, atliekami remiantis šiais principais, ju taikymas ir rezultatų tikslumas yra skirtingi.

2. Apžvelgti šilumos mainų atitvarineje konstrukcijoje skaičiavimo būdai rodo, kad ne visuomet galima tiksliai ịvertinti konstrukciju deformacijas, jų suirimą ar sudegimą, dèl kuriu atitvaroje atsiranda plyšiai, kuriais gali sklisti liepsna.

3. Statybinès medžiagos šiluminès savybès normaliomis sąlygomis nepakankamai apibūdina jos savybes aukštose temperatūrose, nes tai lemia medžiagos struktūra, cheminè sudètis ir pan.

4. Remiantis išdèstyta medžiaga galima teigti, kad būtina plačiau nagrinèti statybiniụ medžiagụ šiluminiụ techninių rodikliụ kaita, atsižvelgiant ị temperatūrą, drègmę, konstrukcijos funkcijas, medžiagos struktüros ypatumus ir pan. Tai ypač aktualu kuriant naujas ugniai atsparias medžiagas arba priemones, gerinančias ši rodikli.

\section{Literatūra}

1. LST ISO 834:1997. Atsparumo ugniai bandymai. Pastatu konstrukcijos elementai. Vilnius: LST, 1997. 29 p.

2. LST EN 1363-1. Atsparumo ugniai bandymai. 1-oji dalis: Pagrindiniai reikalavimai. CEN, 1999. 49 p.

3. STR 2.01.01(2):1999. Esminiai statinio reikalavimai. Gaisrinė sauga / Aplinkos ministerija. Vilnius, 2000. 45 p. 
4. LST L ENV 1991-2-2 Eurokodas 1. Projektavimo pagrindai ir poveikiai konstrukcijoms. 2-2 dalis. Gaisro poveikiai konstrukcijoms. CEN, 1995. $50 \mathrm{p}$.

5. LST L ENV 1992-1-2+AC Eurokodas 2. Gelžbetoninių konstrukciju projektavimas. 1-2 dalis. Bendrosios taisyklès. Konstrukciju gaisrinès saugos projektavimas. CEN. 1995. $85 \mathrm{p}$.

6. LST L ENV 1993-1-2 Eurokodas 3. Plieniniu konstrukcijų projektavimas. 1-2 dalis. Konstrukciju gaisrinès saugos projektavimas. CEN, 1995. $64 \mathrm{p}$.

7. СНиП 2.03.04-84. Пособие по проектированию бетонных и железобетонных конструкций в условиях воздействия повышенных и высоких температур / НИИЖБ. М.: ЦИТС Госстроя СССР, 1989. 82 с.

8. Brandverhalten von Baustoffen und Bauteilen Bauaufsichtlich eingefuhrte Prufnormen DIN 4102. Ratingen: Promat-Buros, 2000. $94 \mathrm{~S}$

9. K. Lukošius, R Mačiulaitis. Akmens vatos gaminiụ temperatūros laidumo analizè aukštu temperatūru sąlygomis // 6-osios tarptautinès konferencijos "Naujos statybinès medžiagos, konstrukcijos ir technologijos", ivykusios Vilniuje 1999 m. gegužès mèn. 19-22 d., straipsniai. IV tomas. V: Technika, 1999, p. 375-380.

10. C. Gosselin, P. Eng. Structural Fire Protection - Predictive Methods. National Research Council of Canada, 1987.

11. В. П. Бушев, В. А. Пчелиншев и др. Огнестойкость зданий. М.: Стройиздат, 1970. 261 с.

12. L. Y. Cooper, J. M. Franssen. A basis for using fire modeling with 1-D thermall analyses of barriers/partitions to simulate 2-D and 3-D barriers/partitions structural performance in real fires, Report NISTIR 6170, BFRL, 1998. $53 \mathrm{p}$.

13. A. A. Šakmanas. Termodinamika ir šilumos mainai ugniagesyboje. Vilnius: Technika, 1996. $44 \mathrm{p}$.

14. B. Karlsson, J. G. Quintiere. Enclosure Fire Dynamics. Dept. of Fire Safety Engineering, Lund University, 1999. $327 \mathrm{p}$.

15. A. E. Cote and J. L. Linville. Fire protection handbook, $16^{\text {th }}$ edition, Fire safety in building design and construction. Quincy, MA: NFPA, 1986, p. 7-82 to 7-108.

16. Д. Драйздеил. Введение в динамику пожаров. Москва: Стройиздат, 1990. 423 с.

17. R. Iding, B. Bresler, Z. Niramuddin. Fire-T3 a computer program for the fire response of structures - Thermal (three dimensional version). NIST Department of Civil Engineering, Report Nr. NIST GCR 95-682. 1996. $156 \mathrm{p}$.

18. U. Wickstrom. TASEF-2 a computer program for temperature analysis of structures exposed to fire, Report 79 2, Dept. of Structural Mechanics, Lund Univesity, 1979.

19. T. T. Lie. A procedure to calculate fire resistance of structural members // Fire and Materials, Vol 8, No 1, NRCC 23574. 1984, p. 40-48.

20. A. Šapalas. Statybinių konstrukcijų atsparumas ugniai. Vilnius: Technika, $1995.40 \mathrm{p}$.
21. В. М. Астапенко, Ю. А. Кошмаров, И. С. Молчадский, А. Н. Шевляков. Термогазодинамика пожаров в помещениях. Москва: Стройиздат, 1988. 448 с.

22. В. Р. Хлевчук, Е. Т. Артыкпаев. Огнезащита металлических конструкций зданий. Москва: Стройиздат, 1973. $97 \mathrm{c}$.

23. Л. А. Сена. Единицы физических величин и их размерности. Москва: Наука, 1977. 335 с

24. S. Kumar. Computer love // Fire prevention 1997 September Hertfordshire: Fire protection association, 1997. p. $46-48$.

Iteikta $2001 \quad 02 \quad 15$

CALCULATION METHODS OF HIGH TEMPERATURE DISTRIBUTION WITHIN STRUCTURAL COMPONENTS AND APPLICATION OF THESE METHODS TO FIRE RESISTANCE ASSESSMENT

\section{R. Mačiulaitis, K. Lukošius}

Summary

Fire resistance of a building structure is one of important properties which describes the behaviour of the structure exposed to fire. Performance based on codes allows to use calculation methods. Given a satisfactory characterisation of the heat exposure, the designer may then compute how quickly temperatures will increase at various sections within the structural component. There are many calculation methods. They can divided into three groups (Fig 1): using experimental data, using both temperature conduction process and nonstationary thermal conduction. Thermal conduction, temperature conduction and thermal capacitance are general properties for temperature prediction methods. Usually building materials have thermal characteristics for normal environment, which can not exactly describe material properties at high temperatures. But many calculation methods lack accurate thermal characteristics describing building material properties at high temperatures. This article is intended for the analysis of this question.

Romualdas MAČIULAITIS. Doctor Habil, Professor. Head of Dept of Building Materials. Vilnius Gediminas Technical University (VGTU), Sauletekio al. 11, LT-2040 Vilnius, Lithuania. E-mail: romualdas.maciulaitis@st.vtu.lt

Doctor (technical sciences, 1980). Doctor Habil (technical sciences, 1993). Professor (1999). Author of more than 120 publications. Research interests: durability, frost resistance, fire prevention and other properties and processes of building materials and products.

Kẹstutis LUKOŠIUS. PhD student. Dept of Building Materials. Vilnius Gediminas Technical University (VGTU), Saulètekio al. 11, LT-2040 Vilnius, Lithuania

E-mail: gtc.kestutis@vpgt.lt

MSc (1999, civil engineer). Co-author of 3 research papers. Research interests: fire resistance of building structures. 